\title{
Velkommen til NFUD sitt symposium 2017
}

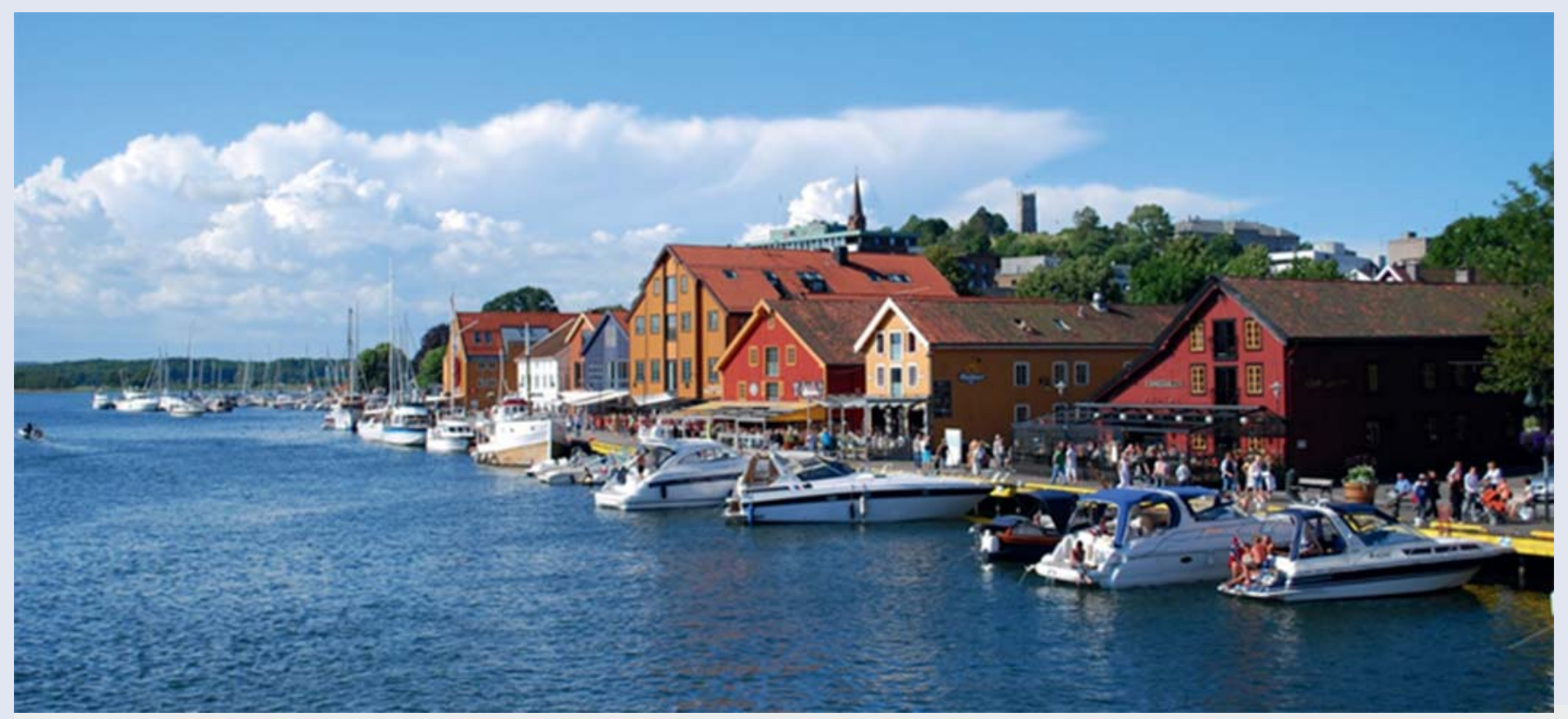

- Fig. 1 Brygga i Tønsberg

Vi vil ønske deg hjertelig velkommen til årets ultralyd symposium 3. - 5. mai 2017.

Symposiet finner sted på Quality Hotel Tønsberg.

Vi har jobbet med å sette sammen et tre dagers program der vi håper alle vil finne forelesninger og praktiske øvelser av interesse. Som vanlig har vi med oss flere norske og utenlandske forelesere. Satsingen på praktiske øvelser og demonstrasjoner har blitt godt mottatt de siste årene. Derfor er også i år store deler av onsdagen og torsdagen forbeholdt parallelsesjoner i de forskjellige fagområdene med fokus på hands-on trening.
Generalforsamlingen avholdes i år allerede på onsdag. Det er flere styremedlemmer og ikke minst styrelederen som skal velges. Egen innkalling til generalforsamlingen vil komme senere.

Onsdag kveld tar vi vare på det sosiale med en "get together" samling på hotellet før festmiddagen arrangeres torsdag kveld.

Frist for innsending av abstrakt for frie og inviterte foredrag, og for å søke forskningsstipendet på 10000 NOK er 7. april 2017. Alle NFUD medlemmer som driver med eller planlegger et ultralydrelatert forskningsprosjekt kan søke om forskningsstipend med en kortfattet prosjektbeskri- velse, og informasjon om hvordan pengene tenkes brukt.

Vi setter i år ingen påmeldingsfrist for selve symposium, men etter 7. april 2017 kan det ikke garanteres for overnatting på kongresshotellet.

Detaljene og programmet finnes på NFUD sin hjemmeside www.nfud.no.

\section{Vi håper å se deg i Tønsberg!}

\section{Styret i NFUD}

